\title{
Strategy at Work
}

Citation for published version (APA):

Letterie, W. (2017). Strategy at Work. Maastricht University. https://doi.org/10.26481/spe.20170609wl

Document status and date:

Published: 09/06/2017

DOI:

10.26481/spe.20170609wl

Document Version:

Publisher's PDF, also known as Version of record

\section{Please check the document version of this publication:}

- A submitted manuscript is the version of the article upon submission and before peer-review. There can be important differences between the submitted version and the official published version of record.

People interested in the research are advised to contact the author for the final version of the publication, or visit the DOI to the publisher's website.

- The final author version and the galley proof are versions of the publication after peer review.

- The final published version features the final layout of the paper including the volume, issue and page numbers.

Link to publication

\footnotetext{
General rights rights.

- You may freely distribute the URL identifying the publication in the public portal. please follow below link for the End User Agreement:

www.umlib.nl/taverne-license

Take down policy

If you believe that this document breaches copyright please contact us at:

repository@maastrichtuniversity.nl

providing details and we will investigate your claim.
}

Copyright and moral rights for the publications made accessible in the public portal are retained by the authors and/or other copyright owners and it is a condition of accessing publications that users recognise and abide by the legal requirements associated with these

- Users may download and print one copy of any publication from the public portal for the purpose of private study or research.

- You may not further distribute the material or use it for any profit-making activity or commercial gain

If the publication is distributed under the terms of Article $25 \mathrm{fa}$ of the Dutch Copyright Act, indicated by the "Taverne" license above, 
prof.dr. Wilko Letterie School of Business and Economics

\section{Strategy at Work}




\title{
Strategy at Work
}

\author{
Wilko Letterie
}

Inaugural Lecture

June 9, 2017

Maastricht University

School of Business and Economics

All rights reserved. No part of this publication may be reproduced, modified, stored in a retrieval system or made public without the prior written permission of the author. 
Mevrouw de Rector, Mijnheer de Decaan, Lieve familie en vrienden, Geachte dames en heren,

The title of the lecture is inspired by the name of a course we teach at the department of Organisation and Strategy. The course is called "Manager at Work". The name was conceived by the late Professor Robert Roe who worked with us until his retirement. It has always been a somewhat intriguing course name to me. The department of Organisation and Strategy offers many managerial insights to students by the courses we offer. One ambition is that our students obtain knowledge of how organisations function and that they learn which factors yield the best outcomes.

At the department of Organisation and Strategy we should know which elements play a role. We teach aspects of strategy formation and the strategic decisions to be made to function well as an organisation. We teach how to reach objectives by setting specific organisational structures. We teach how entrepreneurial activities may yield innovative outcomes. We teach which sorts of managerial behaviour and strategic choices are most desirable for organisational performance.

Some of the research and teaching I was allowed to do may help understanding in what is currently happening at our School of Business and Economics. Hence, on the one hand my lecture shows to you what kind of topics I have been working on and will be working on in terms of research and education. On the other hand, I depict how some of this work may provide insights for our own environment. Therefore the title of the lecture is "Strategy at Work".

\section{Absorptive capacity}

First of all I like to discuss the role of research in organisations. Its function has been analysed quite widely in the context of businesses. This has been documented prominently by the work inspired by Cohen and Levinthal (1990) who have advanced the notion of absorptive capacity. They define the concept of absorptive capacity as "the ability to recognise the value of new, external information, assimilate it and apply it to new commercial ends." In a business environment it has been established well that the conduct of research facilitates building absorptive capacity. According to 
this literature research may actually provide two benefits. To start, research helps in developing new insights. This is the obvious benefit of research. One of its purposes is to learn how certain phenomena work. It is supposed to advance knowledge and learning. The other function of research, and this is maybe the less obvious role, is that by conducting Research and Development firms build ability to recognise valuable developments outside their organisation. Hence, R\&D is not only instrumental in developing new insights. The additional benefit is that $R \& D$ provides a way to connect to the external environment. It provides the glasses to observe relevant developments outside the walls of the entity. One can imagine that especially in the dynamic world we are living in, where knowledge resides at various places, firms need to be able to track and understand what is going on elsewhere.

However, firms cannot survive in the long run by only engaging in research related activities and by only recognising valuable external insights. These activities should yield innovative products or services that allow a firm to sustain a profitable position in a market or to maybe even enter new markets. The ability to commercialise is an equally important part of the absorptive capacity of an organisation. For firms research is not an end in itself. It should be directed at a certain purpose.

A university also conducts research. Of course, university objectives are not equivalent to those of a company. Maastricht University, for instance aims to be a "research university where fundamental and applied research are inextricably linked with education and educational innovation." Hence, the aim is to conduct research and provide academic education. The objective is not to make a profit but to "contribute to a better world" as we can also read at the Maastricht University website. With this in mind one can think of how absorptive capacity may be understood in our academic environment.

Next to discovering new insights oneself, being an active member of the research community allows an academic to recognise early current external developments that are ground-breaking in other parts of the Netherlands, Europe or elsewhere in the World. In order to be able to understand major developments in a discipline for a university it is crucial to conduct research itself at a high level. This research helps in understanding and detecting academic developments somewhere else. 
In a company research is not an end in itself. For a university research is not meant to pursue a commercial end. However, in our context we may have to wonder how research may help in "contributing to a better world" as this is a prime objective of our institution. This notion is also referred to as valorisation in an academic environment. A number of possibilities exist. These are not very surprising ones. Nevertheless, it is good to mention them.

A clear link needs to exist in terms of the research and education we conduct. The research results we produce ourselves and observe somewhere else are valuable in the programmes we offer to our BSc, MSc, $\mathrm{PhD}$ and Post Graduate students. The education we deliver is the main contribution we can provide to society. Raising young professionals who possess valuable knowledge, skills and values is the major way we add something to the world we live in. Our students will work outside of the university most often, and their abilities will find their way in the organisations they work for.

Alternatively, our research may help other organisations directly. Firms may benefit from the work we do by being able to improve performance as they can use and implement managerial insights with a scientifically proven track record. Research may also yield new product or new service offerings. Policymakers may benefit from academic insights by better understanding of human or firm behaviour. Especially in the area of business and economics very often such possibilities exist and a substantial part of the high quality research in these disciplines is applied by its very nature.

Nevertheless, the absorptive capacity story I have depicted earlier starts with research. It is the research quality that makes all of the valorisation we may achieve possible. Research provides new insights, and research provides the ability to take in external insights. Hence, I like to say we need to be careful with top researchers and cherish our young talents. In the end research is the starting point of absorptive capacity. It has to remain strong and it may even have to get better. At the same time we have to consider carefully the other components of absorptive capacity: i.e. the ability to assimilate and apply it to obtain new products and services. 


\section{Flexibility}

A topic I have been working on since I arrived in Maastricht concerns flexibility of decision making. The value of flexibility under conditions of uncertainty is clear. The literature on real options has been able to establish that fact well. When decisions cannot be reversed easily it is better to avoid commitment and build in possibilities to adjust previous decisions or to postpone them (Dixit and Pindyck, 1994). Under situations of uncertainty creating options is desirable. In the context of the School of Business and Economics I foresee a number of potential developments due to which it is recommendable to remain flexible in certain aspects.

First, demand for education at the MSc level may decrease. Alternatively, demand may shift towards other fields of science. For instance, demand for studies in technical sciences may increase at the expense of student numbers in business sciences and economics. Due to such developments one may want to build an option to be able to downscale easily if such a decision is called for. Furthermore, it is prudent to invest in building additional experience in providing MBA or executive programmes to cater to the needs of individuals who need insights from business sciences at a later phase of their professional career. At least, this investment provides the option to be able to provide services in that area later on.

Second, within the fields of business and economics shifts may take place due to societal developments, calling for specialists in other or new disciplines. This may imply that internal labour supply has to shift from one area to another. This requires organisational flexibility. It calls for the ability to develop new in-house fields of expertise. The development of dynamic, strong and visible research themes as we do now helps in this respect. But it remains important to critically reflect upon themes we cover. The development of new or alternative themes, replacing others should be allowed for.

This resembles the idea of dynamic capabilities. This is especially relevant in a dynamic environment (Eisenhardt and Martin, 2000). This means an organisation should be able to develop new competences and sometimes divest ones that are not relevant anymore. Avoiding getting trapped in core competences that become core rigidities is a worst case scenario (Leonard-Barton, 1992). Just recalling how a successful firm like Kodak, once very successful in photography, missed out on digital photography, 
despite having a been a frontrunner in the development of the technology, illustrates this well.

\section{Cooperation}

In order to know "what to do" and "how to do it" learning is required. I have touched upon some aspects related to learning already. For instance, the presence of absorptive capacity is an important ability of an organisation to be receptive to external knowledge. One important way to get access to this knowledge is the formation of alliances (Hagedoorn, 1993). Instead of only seeing other organisations as competitors or potential adversaries, in many instances it is better to cooperate.

Very likely cooperation will remain an important strategic activity of companies to be able to obtain knowledge or to get access to resources. Due to better connectivity of individuals and firms because of the internet, readily available communication, ease of transportation and new production technologies like 3D printing, knowledge and resources will remain and become even more dispersed across the globe. My view is that the ability to form alliances will even become more important, probably also for companies that are not operating in what we refer to as high tech environments. The integration of Biotechnology, and Information and Communication Technology in more and more other industrial settings for instance seems to indicate that distinguishing between low, medium and high tech becomes more difficult. Hence, in many industries alliance management will remain or become a prime capability.

Often a university is well connected. As with firms, input to scientific knowledge, but also insights universities want to transfer to students, is residing at various places in the world. It is the ambition of our university to be a connected entity. We are doing quite well in that respect. For instance, due to the exchange programmes offered to students we already are quite connected formally. The university also participates in the World Universities Network and the Young European Research Universities Network.

However, we may have to ask the question whether we should do more. Maastricht University ranks high in the top 50 under 50 list. We are doing 
very well as a young university. It was founded in 1976 . So our age is 41 , implying in 9 years we will hit the 50 number. We will then be ranked in a different way. Instead, we will be regarded as an established university. Being aware of that, we have to start thinking of how to get closer to the quality standing of more established universities.

To become an important player in a market it is useful to get more formally connected to high status players in the networks that are relevant (Greve, Rowley and Shipilov, 2014). This could be a goal to strive for in the near future I think. Currently, at least as far as I am aware, at SBE we do not have so many visible formal collaborative links with high status universities and organisations. We do have a very interesting tie between Maastricht University and the United Nations as formalised in UNUMERIT. Especially relatively younger organisations can benefit a lot from such quality signals that high status organisations may provide to lower status entities. Borrowing status from such players may offer a lot of external validity to the outside world. This is an opportunity that SBE may consider more strategically given the high quality of some of the key researchers at our school.

I like to make a short observation at this stage of my lecture. An attempt to understand the formation of networks is not exclusively made by business scholars. Business scientists and economists became interested in the topic at about the same time. Whereas typically academics in business often investigate the implications for business performance, economists focus more on under which conditions networks are stable and efficient (Jackson and Wolinksy, 1995). The focus may be different across disciplines, but interest in the phenomenon is common. I return to this comment later.

\section{Dynamic decision making}

The current strategic renewal initiative at SBE is a quite large adjustment from how SBE operated before. Many changes are planned and implemented. Both the business sciences and economics predict that organisations undergo such large departures from the past. Economists would say that the costs to adjust are consisting of fixed components (Hamermesh and Pfann, 1994). Fixed costs are such that the costs are 
independent of the size of the adjustment. In such a case it is better to not adjust for a long time and to adjust only occasionally. Usually, once an adjustment is implemented it is a rather large change.

It is just like running errands. The cost of going to the supermarket, in terms of time spend on going to the shop, or in terms of fuel expenses needed to go by car, is largely the same irrespective of how much is purchased. The time one spends on traveling to the shop and time needed to walk through the shop are mainly independent of the number of items that are bought. In that case it is best to fill up the basket completely and to shop only once a week or so.

Due to fixed cost of adjustment we see that in many instances companies adjust only occasionally. Organisations change infrequently along many dimensions. For example, often firms hire and fire personnel in short periods of time. Furthermore, once adjustment takes place, the size of the change is rather large. Afterwards labour adjustment is rather sluggish for some time. Similarly, the stock of capital goods, for instance the number of machines, is adjusted quite rarely. Additionally, prices that firms charge to their customers are changed only a few times a year typically.

Management sciences predict similar patterns. The idea of punctuated upheaval (Tushman, Newman and Romanelli, 1986) tells that organisations evolve through relatively long periods of stability that are punctuated by rather short episodes of fundamental change. Hence, equilibrium periods are interrupted by revolutionary periods. In this story adjustment is hindered by organisational inertia that has to be broken. Such inertia is often very strong. It takes a substantial managerial effort to pursue adjustment due to which it can only be done occasionally.

Change typically only occurs if the organisation faces a severe crisis in its performance, or if it is subject to major changes in its environment. This is consistent with predictions from the real options theory just mentioned. According to that perspective changes will only be implemented once decision makers are sure that the benefits of change are substantially larger than the costs. Once uncertainty has been resolved, i.e. when a crisis or a major shock hits an organisation, action will be undertaken.

Substantial changes are necessary in the lifetime of organisations once in a while. It is very common. Such change does provide quite some stress and uncertainty to organisational constituents. The new organisational 
settings will not be perfect typically right after the changes have been implemented. Afterwards, the changes have to be evaluated and often fine tuning is necessary. The fit between strategy, structure, people and processes is hardly ever perfect and convergence is a process characterised by ongoing incremental change (Tushman, Newman and Romanelli, 1986). Learning, time and hence patience are required to improve and reach a new equilibrium.

\section{Synergies between business and economics}

The articles I have used for this lecture are not the first ones in their field typically. However they illustrate that business and economic scientists get interested in similar issues at about the same time in quite some instances. At least this holds for the fields I have been interested in for some time already. For instance, the notions of real options and dynamic capabilities both address how firms can build flexibility to be able to deal with changes in their environment. Alternatively, understanding dynamic decision making at the micro level in economics and the theory of punctuated equilibrium advanced in business sciences both tell that organisational changes are made in a lumpy fashion. Change patterns are not smooth processes according to both disciplines but rather they entail sharp deviations from the previous state. Next, studies on network and alliance formation have started to appear more frequently in both business and economics journals rather simultaneously. Strikingly, we have seen very little interaction between the fields.

Partly this may be driven by the different focus of business scientists and economists. While business scholars put emphasis on understanding fundamentals of firm performance, economists very often tend to put their attention on understanding economic behaviour and getting insights into welfare implications for instance.

Nevertheless some of the most interesting researchers these days are capable of being involved in both disciplines. For example, Nick Bloom from Stanford University has been able to address issues in both business and economics very successfully. His research shows that proper understanding of micro level decision making helps understanding macroeconomic developments. He also has done interesting empirical work on 
management practices and their impact. Clearly his work shows that business and economics are very closely linked.

A core asset of SBE is that the fields of business and economics are present in one school. In Maastricht the disciplines are married. They live in one house. So far the marriage has been working quite well. In general at the school the atmosphere is very nice. Nevertheless, we live in a Roman Catholic area. In the old days priests would like to see families with many children. Though I have a protestant background and do not want to be a priest, I wonder whether the couple living at Tongersestraat 53 could be more fertile.

Maybe indeed our happy marriage should result in more offspring. Each discipline has assets that can be more valuable when being used jointly. This I see as one of the main promises of SBE. In fact, business scientists may learn a lot from the methodological rigor employed by economists. Economists may learn from business scientists as the latter often have a very good idea on what is relevant for organisations. Also I see a lot of creativity in business sciences. Combining the strengths of the two disciplines will probably yield research conducted according to higher academic standards and with higher impact.

Realising the promise is not easy. It requires recognising the value and core competences of the different disciplines. The potential benefits are large. In management one would refer to synergy. To be able to obtain synergy complementarities need to exist between entities that are brought together. The presence of complementarities between the business and economics disciplines is plausible as we are working in related areas (Roberts, 2004). The examples of topics like flexibility, cooperation and dynamic decision making I have mentioned previously in this lecture, illustrate the fact that business and economics are related fields. Hence, the potential exists to make the combined scientific fields in one school do better than the sum of its parts. 


\section{Possibilities for joint efforts in business and economics}

Apart from the fact that the disciplines can complement each other in terms of methods and relevance, I see some interesting possibilities to conduct joint research and educational efforts across scientific fields in our School of Business and Economics.

Let me describe some topics I find interesting myself for future multidisciplinary research. One of these topics concerns the formation of networks between organisational entities within companies. Some firms internally organise themselves as centralised hubs. Others are organised as integrated networks (Bartlett and Beamish, 2014). We see such variations also across networks between separate firms. We quite well understand how such types of network configurations influence firm performance (Greve, Rowley and Shipilov, 2014). For instance, hub and spoke networks, where one firm acts as a centre and the others are only linked to the central firm, not with each other, yield highest chances of radical innovation. Nevertheless, the level of trust is not very high in such a setting. In contrast, integrated networks, where most firms are linked to each other, are a better structure when incremental innovation is called for. The level of trust amongst network members is often quite high in this setting.

However, I think we do not know much about how such internal network characteristics affect firm performance. Then the question is whether an internal centralised hub or an internal integrated network performs best. One may not be able to apply results from interfirm networks directly to the within firm setting. One main reason is the fact that in an interfirm setting a firm may act as a broker, playing off one firm against other network constituents. Within the firm the interests of the company's subsidiaries should be largely aligned. Hence, the need to play off network members or the incentive to cheat on them should be less prevalent.

Interesting questions to be addressed still relate to how firm performance depends on these internal structures. A more theoretical question is whether the optimal shape of a network is affected by the fact whether it is organised between firms or within a firm. One may also wonder whether internal or external networks work best. The question then becomes whether networks should be internal or external to the firm boundaries. Such questions require both empirical and theoretical 
approaches. Both business scholars and economists may find such questions worthy of investigation.

Another topic that has the potential for multidisciplinary research within SBE is as follows. In the department of Organisation and Strategy we have mainly focused on network formation and how this relates to the development of technologies. However, by cooperating with SBE colleagues from the Marketing group I have learned recently many firms in manufacturing industries are also aiming at improving service levels these days. When competition is strong, differentiation may be possible along the dimension of services provided to customers. Interesting questions prevail to what extent collaboration with partners located at different places in the value chain yield performance benefits and under which conditions this is most likely.

Multidisciplinary research is also needed to make further steps into getting better understanding of heterogeneity in adjustment processes employed by firms. In economics we know quite well how to build structural models that are capable of explaining the patterns we observe. Business sciences provide a quite good understanding of the processes that underlie the phenomena we observe when organisations change. Nevertheless, we still have limited knowledge concerning the various adjustment technologies available to firms. We may invest in acquiring knowledge of how such adjustment technologies depend on firm or industry characteristics. Obtaining more fine grained knowledge requires combining insights, research methodologies and methods of data collection as employed by various disciplines at SBE.

In terms of educational innovation I am looking forward to see members of the department of Organisation and Strategy, including myself, being involved in themes like for instance Conflict and Cooperation, the Human Side of Business, and Sustainability that currently are under construction at SBE. Such themes are embedded well in the school in terms of research capacity and potential. Clear possibilities exist in terms of conducting joint research and joint teaching efforts. Setting up multidisciplinary MSc programmes on Conflict and Cooperation but also in Sustainability should be feasible. Both topics can be advanced from a business and microeconomic and macro-economic perspective. Our school is the appropriate setting to build up such programmes. I think we have done well with these themes if in three years from now or so we can offer an MSc on Conflict 
and Cooperation in which students can also learn skills that are related to these topics. Skills related to conflict management, negotiation, dealing with diversity are obvious candidates. Another MSc programme I have good hopes for is the one on Sustainable Management or Management of Sustainability. In such a programme essentially all SBE disciplines can participate I imagine.

\section{Conclusion}

Currently I am a manager mainly. I regret to say that to quite some extent as I realise that it comes at the cost of having less time for being able to do research. Now I am a "Manager at Work." As a chair of the department I am managing on an almost daily basis.

By education I am an econometrician. My PhD thesis dealt with Political Economics. My research in Maastricht started touching upon strategy oriented topics when I came to south of The Netherlands almost twenty years ago. Approximately five years ago, when I started being involved at the Graduate School of Business and Economics, I got my first real managerial assignments. This means I am still learning a lot about the practical side of being a manager. Making mistakes I do on a regular basis. Making mistakes comes with taking risks and experimentation. Making mistakes also comes with my communication style I imagine. Having my roots in Rotterdam and hence not being very fond of many words does not help either.

As my story line indicates, I did not obtain a formal training as a manager really. So I hope the O\&S department members have some patience with me still. I am open to learn and receive feedback if you find that necessary. Being surrounded by Organisation, Entrepreneurship and Strategy scholars, I expect to receive input but also initiative in fact. I hope you also will be making mistakes, as I see it as a necessary condition for being successful in the end. To be sure, I like to mention that making mistakes is not an end in itself. Let me maybe be clear about that. However, when making decisions under uncertainty, things can go wrong. The challenge is to be willing to accept prudential risks and stop the failures as soon as possible. For that we need transparency, communication and support from each other. 
In this lecture I have touched upon a number of insights for a "Strategy at Work" obtained from strategy scholars with a background from both business and economics. Resuming, in knowledge intensive organisations their absorptive capacity is a key determinant of organisational performance. Innovation outcomes and long term performance largely depend on it. High quality research is the key driver of this absorptive capacity. Let me stress that. One other important aspect of organisational absorptive capacity is the ability to bring innovations to the market. At SBE a better connection of research and education is likely to be valuable. Connections to stakeholders are important as well to understand the needs of students and their future employers. These needs may change and research is dynamic as well. New topics emerge and new fields pop up. This requires some flexibility. Organisational resources and competences need to be adjusted once in a while. Dynamic capabilities are called for. Processes need to be in place to make sure an organisation continuously remains open to innovation.

Learning by cooperation has proven useful very often. Firms tie up with all kinds of other organisations to be able to obtain insights from others. The ability of allying with others is an example of a dynamic capability. This is often institutionalised at the organisational level such that in a firm a dedicated alliance function has been created (Greve, Rowley and Shipilov, 2014). By having such an entity within the organisation knowledge about how to form partnerships is centralised and made available to other parts of the organisation. If Maastricht University wants to still improve on being interconnected, it probably needs to formalise such ambitions in terms of its organisational structure more strongly.

Sometimes organisational changes need to be implemented that call for a quite dramatic departure from the past. Adjustment technologies are such that gradual adjustment often does not suffice to get organisations on the right track. Such changes are very costly. Then many interruptions take place due to which important activities are getting less attention. This should be prevented as much as possible to not risk individual careers of young colleagues especially. Some investments need to be made available to allow for time needed to develop new MSc programmes, new research themes etc.

Merging entities into one organisation should only be done when complementarities exist. Many companies split at some point when these 
complementarities are not present. In that case the value of the entities may actually be higher when treating them as separate parts. Some firms indeed sell off part of the company. Then they divorce. Currently we have a School of Business and Economics. My impression is that we did not take full advantage of the complementarities that exist yet. Organising our research and education along themes may help in that respect. The disciplines should not divorce in our SBE case. Having the two disciplines joined in one school is an asset. However, the pursuit of synergy between business and economics within the school has to be high on the agenda.

Where SBE may resemble a two person household composed by Business and Economics, Maastricht University resembles a small village of households. Though I do not recommend being unfaithful to partners in general, at the level of the university our offspring may be more diverse and become more resilient by getting in DNA from different parents. Possibilities exist to start interfaculty programmes as well. One may think of MSc programmes like Business and Law, or Economics and Law. I am still somewhat surprised, to put it very mildly, these opportunities have not been taken yet. I am sure many other opportunities are available as well. Of course in a small village one should avoid inbreeding. Hence looking for influx of ideas offered by distant partners is crucial. To get in the external ideas a high absorptive capacity fed by high quality research and strong links between research and education are crucial. Cooperation and engaging in internal and external networks by academics but also by the school and university are fundamental in the dynamic environment we work in. It calls for a more strategic approach to do that in order to obtain a high status and a higher degree of flexibility which may be needed in the future to be able to cope with changes in our environment.

One short note I like to make. In the new strategic programme of Maastricht University I read that Problem Based Learning is a core principle. This of course should be no surprise to us. We may consider working more deliberately according to what may be referred to as Problem Based Research. To differentiate ourselves well from other universities, being "problem based" along more than one dimension could be a unique selling point and a proper part of our "Strategy at Work". 


\section{Dankwoord}

$\mathrm{Nu}$ zal ik in het Nederlands een einde maken aan deze lezing. Dat ik hier nu mag staan is een voorrecht. Voor een deel gebaseerd op mogelijkheden die ik puur toevallig heb gekregen. Daarnaast is de ontwikkeling die ik heb mogen doormaken gevoed door vele mensen om mij en mijn gezin heen.

Het begin van mijn academische loopbaan is te danken aan de inspiratie die ik vond aan de Erasmus Universiteit van Rotterdam. Tijdens mijn studie werd mijn belangstelling gewekt door het werk en de persoon van Otto Swank. Hij werd begeleider van mijn proefschrift samen met Jan Siebrand. Dank zij hen heb ik de eerste stappen gezet in de academie.

Gerard Pfann heeft me destijds overgehaald naar het zuiden van Nederland te verhuizen en te beginnen met iets heel nieuws. Ik kwam in aanraking met nieuwe en spannende onderwerpen op het gebied van investeringsbeslissingen op bedrijfsniveau. Ook maakte ik kennis met een compleet andere onderwijsbenadering. Deze overgang van onderwerp en aanpak van onderzoek en onderwijs heeft me veranderd. Dank je wel Gerard voor de ontwikkelingsmogelijkheden die je me geboden hebt, voor je steun en geduld op vele momenten en je scherpe wetenschappelijke visie.

Op zeker moment kon mijn werk ingebed worden in de toenmalige vakgroep Strategie. Ik maakte kennis met het werk van John Hagedoorn. We hebben in een heel aantal projecten betreffende alliantievorming en netwerkformatie mogen samenwerken. Het was een inspirerende tijd. John, van harte dank voor de ondersteuning van mijn loopbaan.

$\mathrm{Na}$ elf jaar mocht ik Martin Carree opvolgen als hoofd van het departement. We hebben geen artikelen samen geschreven. Je hebt me wel langdurig gecoacht. Daar ben ik me van bewust. Ook op de achtergrond heb je het nodige voor me betekent. Dank Martin.

Deze personen waren mijn leidinggevenden door de jaren heen. Stuk voor stuk bijzondere mensen. Op het werk zijn er echter veel mensen die me hebben geinspireerd en me veel van het leven hebben laten zien. Ik noem de departementsleden van Organisatie en Strategie, promovendi en de vele studenten natuurlijk die zowel kristisch als bemoedigend zijn geweest. Speciale dank wil ik uiten aan Adela Buttolo en Anita Weijzen 
voor hun dagelijkse hulp. Door de jaren heen heb ik ook met veel mensen mogen samenwerken aan onderzoek. Wat heb ik veel van mijn coauteurs geleerd.

Echter ook buiten het departement heb ik veel mogen meekrijgen van collega's, zowel van wetenschappers, als ook van normale mensen. Als tutorverdeler heb ik veel bezoekjes gebracht aan de derde verdieping van de school. Veel dank ben ik verschuldigd aan de collega's op de roosterkamer van de faculteit. Dank voor jullie toegankelijkheid al die jaren. Het is jullie verdienste dat ik heb ingezien dat het werk achter de schermen van het onderwijs en onderzoek zo essentieel is.

Veel vrienden om het gezin heen hebben ons leven verrijkt. Oude en nieuwe vrienden wil ik van harte danken voor al het plezier, hulp, begrip en steun die we van jullie mochten ontvangen.

Doordat ik mijn leven heb mogen binden aan dat van Lotte heb ik een schat aan schoonfamilie gekregen. Op vele momenten hebben zij van alles met ons gedeeld. In gedachten zijn de lieve Jan en Adrie.

Bijzondere dank aan mijn ouders, Paul en Miep. Mijn ouders hebben met hun liefde en zorgzaamheid de basis gelegd voor het rijke leven dat mijn gezin en ik mogen hebben. Tevens hebben Marijke, Paul en Patricea me in onze jeugd en in het heden waardevolle inzichten van wat belangrijk is in het leven kunnen bijbrengen. Dank jullie allen daarvoor.

Tot slot wil ik me richten tot Lotte, Rik en Maartje. Rik woont nu in Amsterdam. Toch voelt het niet ver weg. Ik ben blij met jullie dagelijkse nabijheid. Graag laat ik nog eens bij deze weten hoe jullie mijn grenzen in vele opzichten hebben verlegd. Jullie zijn me zeer dierbaar.

Ik heb gezegd.

Maastricht, Juni 2017 


\section{References}

Bartlett, C.A. and Beamish, P.W. (2014), Transnational management. Text, cases, and readings in cross-border management. $7^{\text {th }}$ Edition. McGraw-Hill.

Cohen, W.M. and Levinthal, D.A. (1990), Absorptive capacity: A new perspective on learning and innovation. Administrative Science Quarterly, $35,128-152$.

Dixit, A.K. and Pindyck, R.S. (1994), Investment under uncertainty. Princeton University Press.

Eisenhardt, K.M. and Martin, J.A. (2000), Dynamic capabilities: What are they? Strategic Management Journal, 21, 1105-1121.

Greve, H., Rowley, T. and Shipilov, A. (2014), Network advantage. How to unlock value from your alliances and partnerships. Jossey-Bass.

Hagedoorn, J. (1993), Understanding the rationale of strategic technology partnering: Interorganisational modes of cooperation and sectoral differences. Strategic Management Journal, 14, 371-385.

Hamermesh, D.S. and Pfann, G.A. (1996), Adjustment costs in factor demand. Journal of Economic Literature, 34, 1164-1292.

Jackson, M.O. and Wolinksy, J. (1996), A strategic model of social and economic networks. Journal of Economic Theory, 71, 44-74.

Leonard-Barton, D. (1992), Core capabilities and core rigidities: A paradox in managing new product development. Strategic Management Journal, 13, 111-125.

Roberts, J. (2004), The modern firm. Organisational design for performance and growth. Oxford University Press.

Tushman, M.L., Newman, W.H. and Romanelli, E. (1986), Convergence and upheaval: Managing the unsteady pace of organisational evolution. California Management Review, 29, 29-44.

Note: I have chosen to not refer to articles I have co-authored. I leave it to those interested to see how they are connected to this lecture. 